\title{
ASSESSMENT OF COHERENT PROPERTIES OF WATER FROM NATURAL SOURCES USING KIRLIANPHOTOGRAPHY OF WATER
}

\author{
Ozar Mintser \\ Doctor of Medical Sciences, Professor, Shupyk National Medical Academy \\ of Postgraduate Education, Ukraine \\ e-mail: o.mintser@gmail.com,orcid.org/0000-0002-7224-4886
}

\begin{abstract}
Liudmyla Pisotska
Doctor of Medical Sciences, Assistant Professor, Dnipro State Medical University, Ukraine e-mail: Lpesotskaya23@gmail.com,orcid.org/0000-0002-0784-1465
\end{abstract}

\section{Nadiia Stetsula}

Candidate of Biological Sciences, Assistant Professor, Drohobych Ivan Franko State Pedagogical University, Ukraine e-mail: n.stetsula@gmail.com,orcid.org/0000-0002-0129-7331

\section{Vasyl Stakhiv}

Candidate of Biological Sciences, Assistant Professor, Drohobych Ivan Franko State Pedagogical University, Ukraine e-mail: vasylstakhiv@ukr.net, orcid.org/0000-0002-8393-1120

\author{
Larysa Kutalo \\ KU «DMTTSSO» (NSP) «DMR m. Dnipro», Ukraine \\ e-mail: larisa9405@gmail.com,orcid.org/0000-0002-5231-1607
}

\begin{abstract}
Summary
The article assessed the condition of the coherent properties of experimental water samples from natural sources in comparison with the results of a biological growth test. Carried out kirlianographic (Ki-photograph) study of 3 water samples from the natural springs of Skhidnitsa, including one sample from the pump room, were carried out. Present the criteria for coherent water for experimentally prepared using distilled water (KGD) and natural drinking water (KGP). According to the data presented, it can be seen that, according to the predominant features of the experimental water samples, the properties of the following coherence types are inherent in them: water from source $1-$ coherent levorotatory 1 st and 3 rd degrees of coherence ( $52 \%$ and $17 \%$ of signs, respectively); water from the source 26 - coherent both types of direction, more levorotatory 1 st degree ( $42 \%$ of signs) and dextrorotatory 1 st degree (17\%); water from source 10 (pump room) - coherent of both types of direction, more dextrorotatory, mainly with the 1 st degree of coherence $(46 \%)$, and the presence of levorotatory coherence of the 1 st (21\%) and 3rd degrees (21\%). The presented results of biological growth demonstrate their differences among themselves, as well as the established properties of experimental water samples in terms of its coherence properties. It is necessary to further develop the direction of studying fine-material processes in water by the method of kirlianphotography with the development of an automated analysis of kirlianograms.
\end{abstract}

Keywords: coherent properties, natural sources, Skhidnitsa, kirlianographic research, distilled water, growth test.

DOI: https://doi.org/10.23856/4719 


\section{Introduction}

Academician V.I. Vernadsky defined water as a bioinert substance. That is, natural water is the result of the interaction of inert and living bodies of the biosphere. At the same time, being a significant part of living matter, water acquires new structural features and physical properties characteristic for it (Vernadskij, 2004).

It is obvious that the health-improving effect of water from natural medicinal sources is directly related to its inherent similar properties. This determines the bioavailability of such water to the human body and its maximum «assimilation», that is, inclusion in metabolism.

The progenitor water «absorbed «the energy of volcanic eruptions in the geochemical epoch of the earth's evolution - molten minerals, vapors of their chemical elements, the energies of the Cosmos characteristic for that time. That is, it was high-energy, active forms of chemical elements from their high ionization prevailed, there were practically no rocks, solid earth.

Today, the latter factors more significantly determine the properties of natural water, its energy, structure and fractality. It takes the structure and fractality of the pattern, determined primarily by the composition, structure and energy of the minerals with which it contacts (Kurik \& Pesockaja, 2014). The influence of dense terrestrial matter on water determines its physicochemical properties, available for study by known physical methods (electrical conductivity, solubility of impurities, $\mathrm{ROP}, \mathrm{pH}$, etc.). However, they do not reveal the state of fine energy-electric relationships of water nanostructures caused by weak field interactions (Kurik et al., 2015). However, the activity of water in living systems is associated just with the latter (Voejkov, 2009).

Revealing the features of fine structures of water is possible by its natural glow, enhanced in a high voltage field, which is known as the Kirlian Effect (Kirlian \& Kirlian, 1957; Koltovoj, 2015; Korotkov \& Jakovleva, 2014).

Previously, we studied Kirlian images of water on an X-ray film to assess its energy (Pisotska \& Hlukhova, 2014; Pesockaja et al., 2016) on an experimental device "PEK 1" (Pesockaja, 2015; Pisotska et al., 2007). Figures 1, 2 show examples of Kirlian photographs of water samples with different mineral composition.

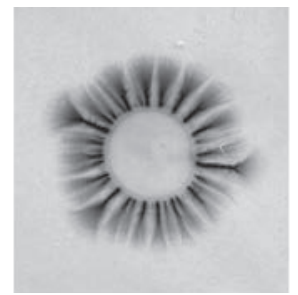

Waterfall of colored stones

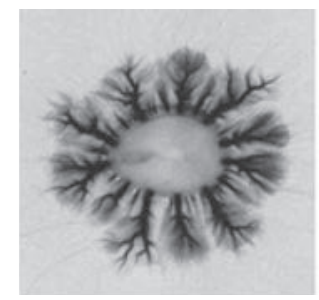

Source Krasnokamenka

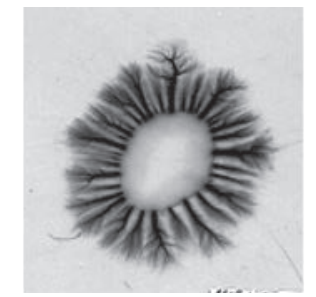

Source on

Karadag

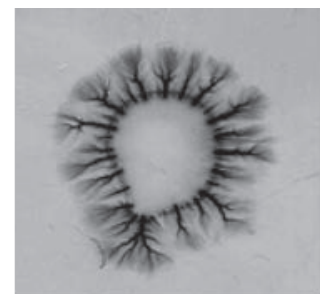

Epiphany spring

Kirlian-glow of water samples from natural sources of Crimea

In the presented photos, the water from the source at a higher point of the Crimean Mountains according to the signs of the Kirlian glow, established by us, is closer to the water from the holy springs. The glow crown of such water is of moderate intensity, with clear long streamers, and a light inner circle. Water from a source located lower in the sea level (downstream of Magdus) has signs of a degenerative type of luminescence according to P. Mandel 


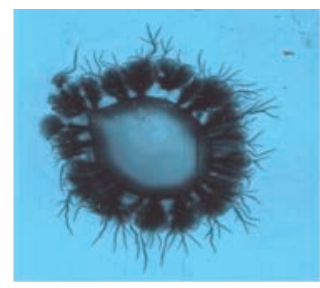

Jodis concentrate

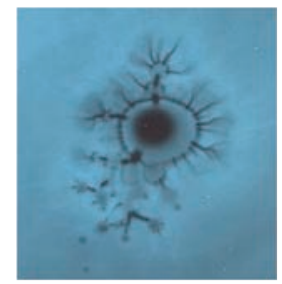

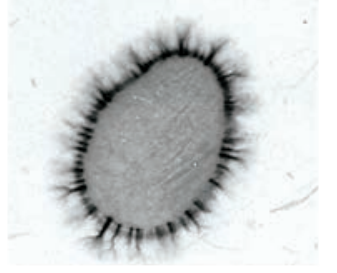

Ferrous water

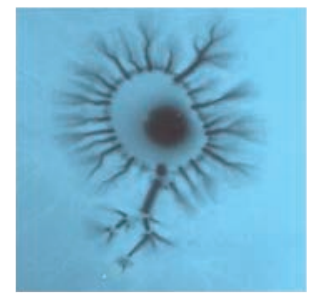

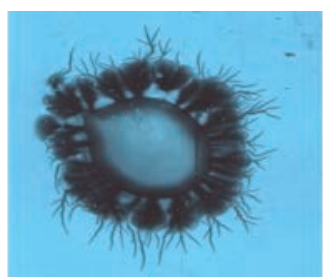

Silver water

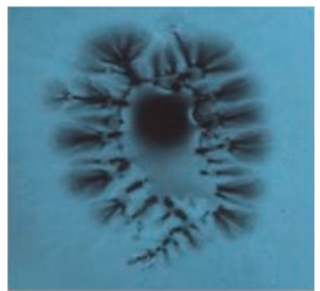

Silicon-shungite water

Kirlian-glow of water from holy springs

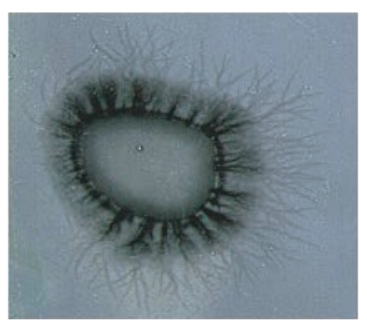

Sofiyivsky Park

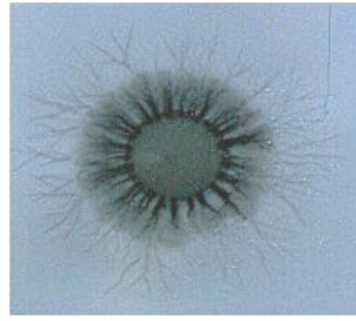

Toplovsky monastery

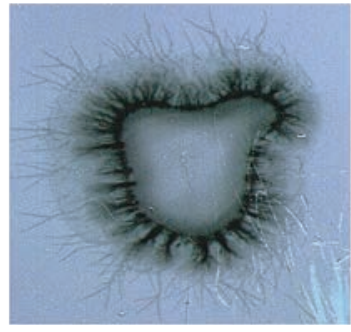

Optina Pustyn

Fig. 1. Examples of Kirlian-glow of water from natural sources with different mineral composition from different terrain

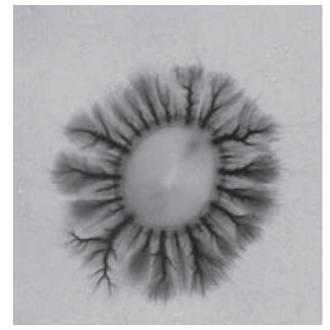

"Pear glade"

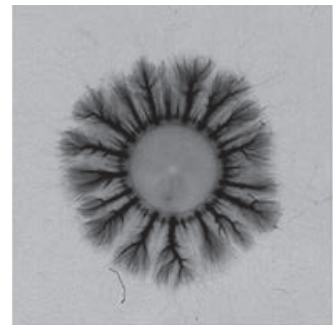

"Magdus"

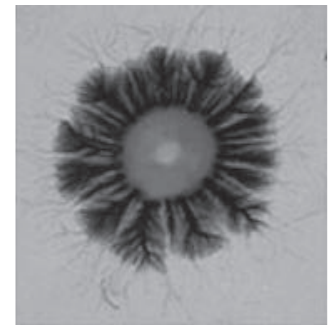

Downstream of "Magdus"

Fig. 2. Kirlian-glow of water samples from different heights above sea level of the Crimean Mountains 
(the least physiological), with a blurred streamer pattern against the background of an increase in the general luminescence, corresponding to dystrophic and structural cellular changes in the human body (Mandel, 1983).

The crown of the glow of water from the sources of holy places draws attention to the presence, in addition to the inner and streamer circle, characteristic of the above water samples, additional circles of glow, different in the image pattern, as well as luminescence lighter than the background of the film. Such features of the images of the Kirlian glow at natural sources outside the territories of monasteries were not observed and have not been described in the literature. The presence of external thin rays of luminescence in such water is similar to those in samples of blood cell material (Kurik \& Pesockaja, 2014).

Recent advances in the study of the biological properties of water have identified the effects on the body associated with coherence. The phenomenon of coherence has become widespread in the description of physical states of matter united by a common feature - the orderly and consistent behavior of a large number of elements in the substance. Superconductivity, superfluidity, laser beam and other phenomena arise due to coherence on a macroscopic scale. At present, the relevance of the issue of creating coherent matter has become so high that such matter was called the fifth state of matter. This is due to the fact that macroscopic coherence leads to the emergence of completely new physical properties of matter, which make it possible to use it in various forms and on an «industrial scale». A distinctive property of a coherent substance is a disproportionately strong response to external influences.

In vitro and in vivo studies have shown that coherent water activates the production of interferon, significantly increasing the effectiveness of inhibition for the vesicular stomatitis virus, the protective functions of the immune system against herpes infection, activates the inhibition of HIV, opportunistic diseases; does not cause aberrations (breakdowns) of chromosomes and is not toxic (Krasnobryzhev \& Kurik, 2010; Krasnobryzhev, 2012).

Therefore, the development of criteria for the rapid assessment of the coherent properties of water is relevant, important for the practice. Since they determine the electrophysical properties of water, it is possible to use methods based on the Kirlian Effect to solve this problem. The latter allows to visualize them and fix them on photographic material. It is optimal to use an X-ray film recording the ultraviolet part of the spectrum, to which the Kirlian glow belongs. The Kilian photography method opens up the possibility of studying fine structural and energy processes of water bodies.

The ongoing research in this area requires comparison with the results of biological tests to understand the significance of different types and degrees of water coherence.

The aim of the work was to assess the state of the coherent properties of experimental water samples from natural sources in comparison with the results of a biological growth test.

\section{Research material and methods}

Kirlianographic (Ki-photograph) study of 3 water samples from the natural springs of Skhidnitsa, including one sample from the pump room, were carried out.

To obtain a Kirlian image of water samples, an X-ray film, an experimental device with an attachment for liquid-phase objects were used (Krasnobryzhev \& Kurik, 2010; Krasnobryzhev, 2012).

Previously, a database of Ki-images on X-ray film for several types of water was created. The following were used as typical waters (TW): distilled (TW1), tap (TW2), natural outside (TW3) and from the territories of monasteries (monastery, TW4). When constructing an automated classification system by water types, the construction of histograms was used as the main method for comparing the geometric and photometric (i.e. brightness) characteristics of images (Pisotska \& Hlukhova, 2014; Pesockaja et al., 2016). 
Kirlianograms of water droplets in the amount of 50 for each test sample under study were scanned and the values of the Euclidean distance were programmatically calculated from the brightness histograms for the medians of the histogram columns heights of 12 subranges on the graph (EPM, a.u.), as well as the differences in heights in adjacent intervals with the values of typical waters (EPRM, cu). The smallest values of the Euclidean distance indicate the maximum closeness of the test sample to one of the typical classes of water.

Figure 3 shows an example of a histogram for the brightness of the luminescence corona (BLC) of the studied water sample in comparison with the established standards of the above-mentioned samples.
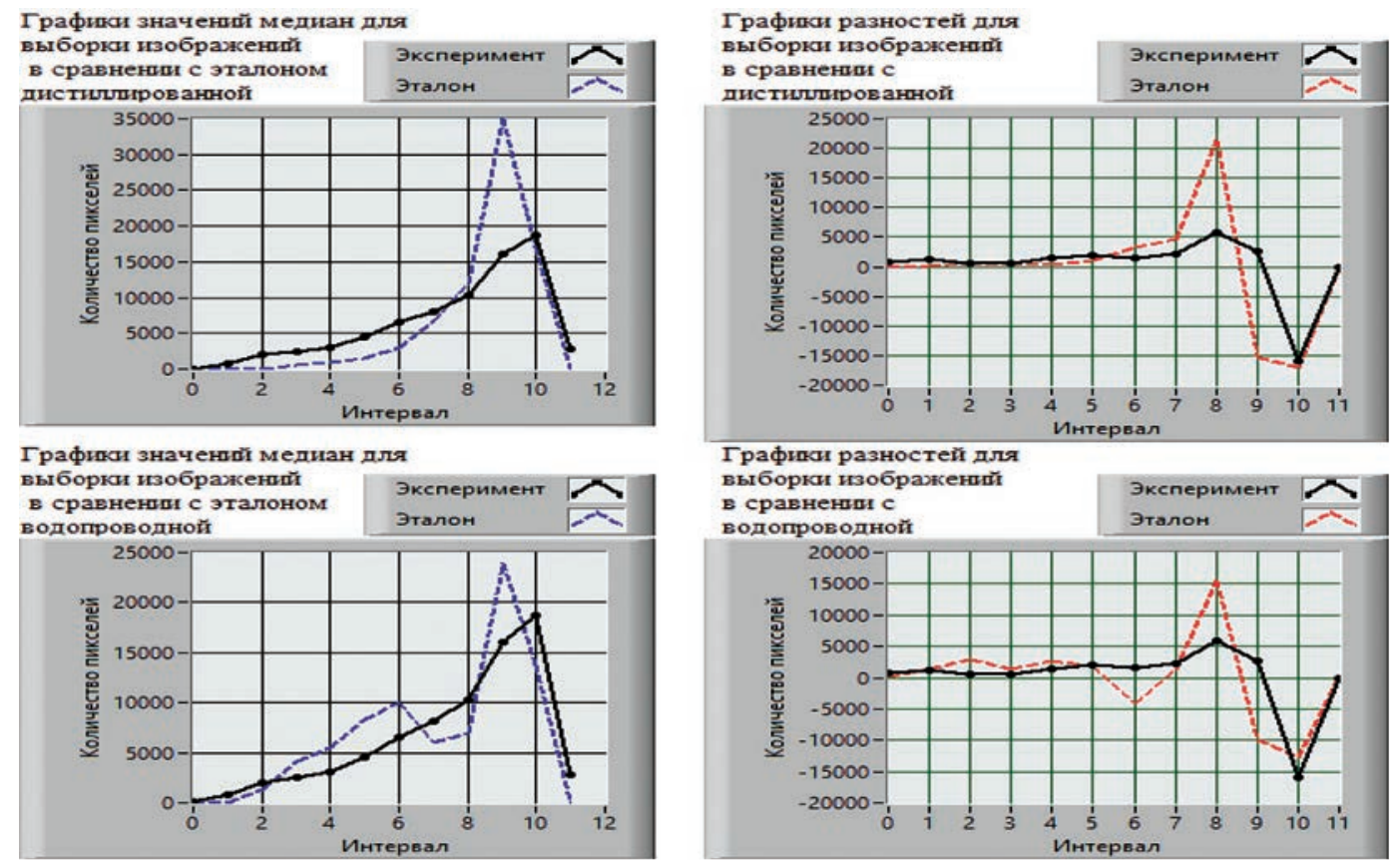

Fig. 3. An example of a histogram for the brightness of the studied water sample in comparison with the established standards of the above-mentioned samples

Previously, we used the EPM and EPPM values of the YAC histograms on an X-ray film to establish the criteria for the type and degree of coherent water experimentally prepared on distilled and natural drinking water (Pesockaja et al., 2016) by teleportation (Krasnobryzhev, 2007). The obtained results of the water samples study were compared with the established criteria for coherent waters.

An analysis of seed germination for 2 types of zucchini using water samples in comparison with their established coherence properties was conducted.

\section{Results and Discussion}

Tables 1 and 2 present the criteria for coherent water for experimentally prepared using distilled water (KGD) and natural drinking water (KGP). 
$\frac{1}{\frac{0}{0}}$

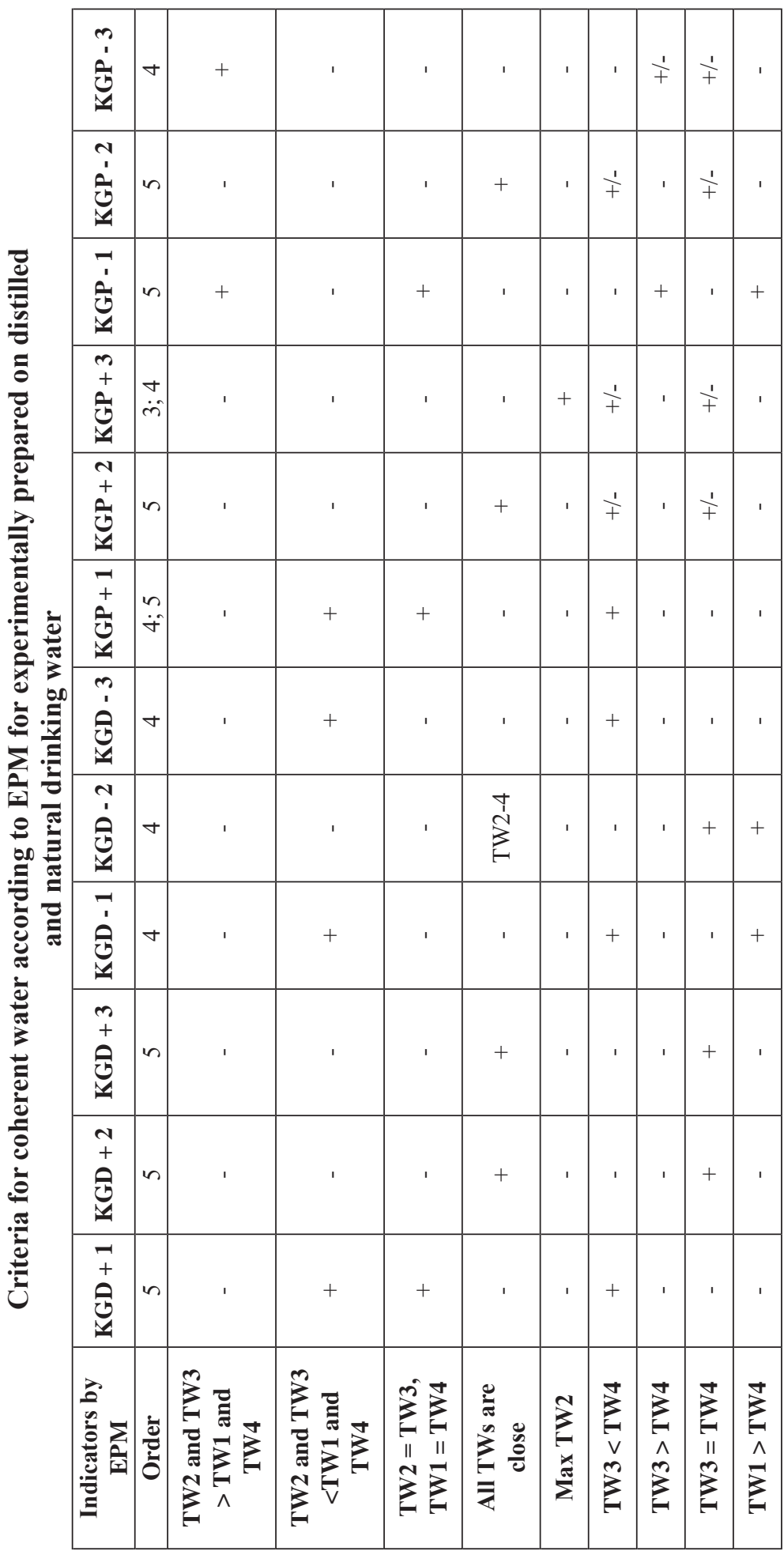


$\frac{0}{\frac{0}{2}}$

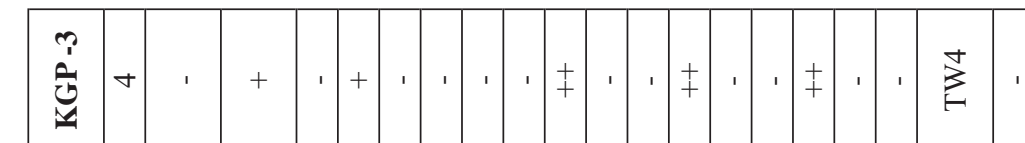

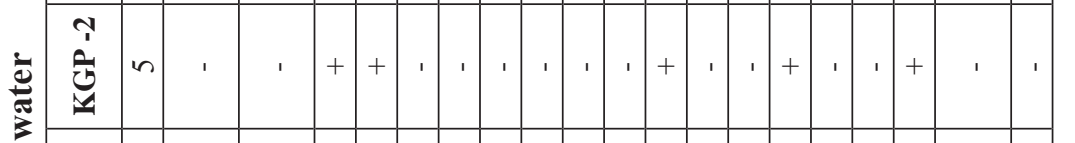

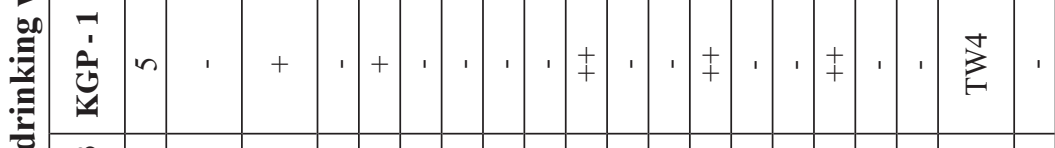

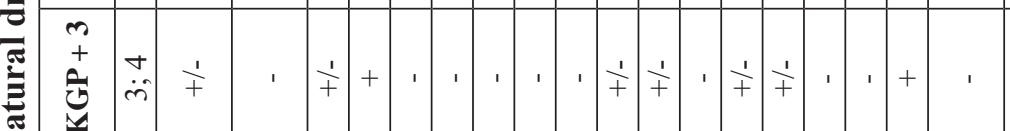

光

를

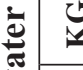

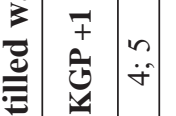

를

ह

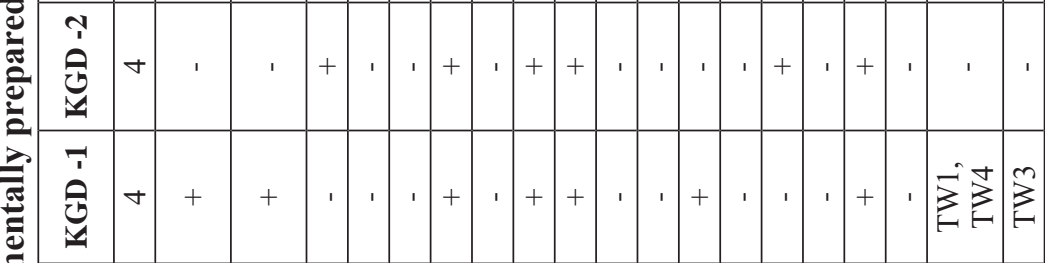

势

齐

文

$\stackrel{2}{2}$

든

¿

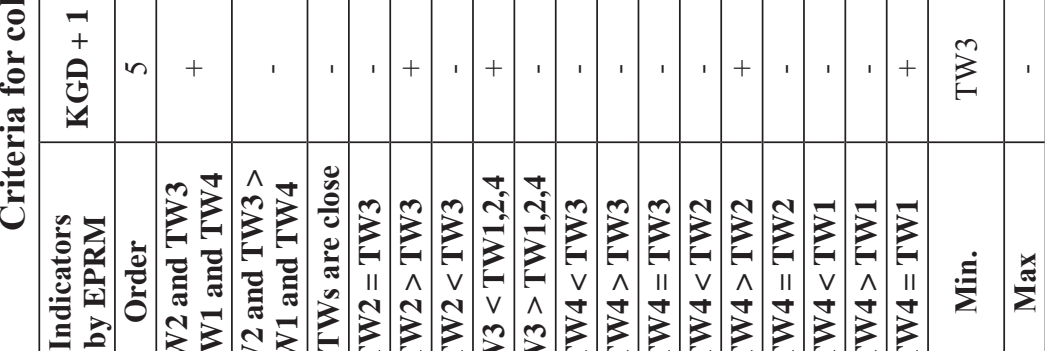

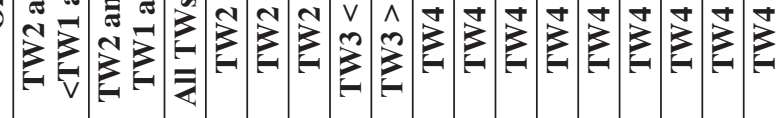


Table 3 shows the physicochemical data of the samples of the investigated mineral medicinal waters from the springs of the Skhidnitsa deposit.

Table 3

Physicochemical characteristics of the studied water samples

\begin{tabular}{|c|c|c|c|c|}
\hline Sample No. & $\begin{array}{c}\text { No. } \\
\text { of the source }\end{array}$ & ORP, $\mathbf{m V}$ & $\mathbf{p H}$ & $\begin{array}{c}\text { IS, } \\
\mathbf{~ m V}\end{array}$ \\
\hline 1 & 10 & 2 & 7.02 & 237 \\
\hline 2 & 26 & -127 & 7.34 & 347 \\
\hline 3 & 1 & -144 & 7.45 & 357 \\
\hline
\end{tabular}

Note: samples 1 and 2 are from the source directly, sample 3 is from the pump room

Table 4 shows the results of the analysis for Kirlian photographs of experimental water samples.

Table 4

Indicators of brightness histograms of test water samples in comparison with samples of typical water classes

\begin{tabular}{|c|c|c|c|c|c|c|c|c|}
\hline $\begin{array}{c}\text { No. } \\
\text { of the } \\
\text { specimen }\end{array}$ & $\begin{array}{c}\text { ER for } \\
\text { med. } \\
\text { Type 1 }\end{array}$ & $\begin{array}{c}\text { ER for } \\
\text { med. } \\
\text { Type 2 }\end{array}$ & $\begin{array}{c}\text { ER for } \\
\text { med. } \\
\text { Type 3 }\end{array}$ & $\begin{array}{c}\text { ER for } \\
\text { med. } \\
\text { Type 4 }\end{array}$ & $\begin{array}{c}\text { ER for } \\
\text { misc. } \\
\text { Type 1 }\end{array}$ & $\begin{array}{c}\text { ER for } \\
\text { misc. } \\
\text { Type 2 }\end{array}$ & $\begin{array}{c}\text { ER for } \\
\text { misc. } \\
\text { Type 3 }\end{array}$ & $\begin{array}{c}\text { ER for } \\
\text { misc. } \\
\text { Type 4 }\end{array}$ \\
\hline 1 & 20151.9 & 12136.9 & 7255.8 & 22492.1 & 24040.7 & 17327.8 & 13908.2 & 30534.7 \\
\hline 2 & 8169.09 & 17101.1 & 15221.3 & 7313.64 & 9977.75 & 16437.3 & 15755.7 & 11417.8 \\
\hline 3 & 13185.8 & 24496.7 & 23906.2 & 9134.41 & 14714.1 & 24299.9 & 24757.9 & 9614.48 \\
\hline
\end{tabular}

Tables 5 and 6 show the results of comparing the obtained values with the criteria for coherent waters with different spin directions - right (+) and left (-) and the degree of coherence (Vernadskij, 2004; Kurik \& Pesockaja, 2014; Kurik et al., 2015).

The following results were obtained in terms of the degree of differences for above these indicators. TW3 is 2.6 times higher than TW4 for water sample from source 1; TW2 is 2.5 times higher than TW4; TW1 is 1.5 times higher than TW4; min. TW4 is 2.6 times less than the maximum TW2 and TW3.

TW3 is 1.4 times higher than TW4 for a water sample from source 26; TW2 is 1.4 times higher than TW4

Table 5

Correspondence of EPM indices according to histograms of Kirlian photographs luminescence for experimental water samples to the type and degrees of experimental coherent water

\begin{tabular}{|c|c|c|c|c|c|c|c|}
\hline $\begin{array}{c}\text { Sign } \\
\text { No. }\end{array}$ & Signs & $\begin{array}{c}\text { Source } \\
\mathbf{1}\end{array}$ & $\begin{array}{c}\text { Source } \\
\mathbf{2 6}\end{array}$ & $\begin{array}{c}\text { Source 10 } \\
\text { (pump room) }\end{array}$ & $\begin{array}{c}\text { Coherence } \\
\text { Source 1 }\end{array}$ & $\begin{array}{c}\text { Coherence } \\
\text { Source 26 }\end{array}$ & $\begin{array}{c}\text { Coherence } \\
\text { Source 10 }\end{array}$ \\
\hline $\mathbf{1}$ & $\mathbf{2}$ & $\mathbf{3}$ & $\mathbf{4}$ & $\mathbf{5}$ & $\mathbf{6}$ & $\mathbf{7}$ & $\mathbf{8}$ \\
\hline 1 & $\begin{array}{c}\text { Order of } \\
\text { magnitude }\end{array}$ & $5 ; 4$ & $4 / 5$ & $5 ; 4$ & & & \\
\hline 2 & $\begin{array}{c}\text { TW2 and } \\
\text { TW3 } \\
>\text { TW1 and } \\
\text { TW4 }\end{array}$ & + & - & - & $\begin{array}{c}\text { KGP(-1) } \\
\text { KGP(-3) }\end{array}$ & - & - \\
\hline
\end{tabular}


Table 5 (Continued)

\begin{tabular}{|c|c|c|c|c|c|c|c|}
\hline 1 & 2 & 3 & 4 & 5 & 6 & 7 & 8 \\
\hline 3 & $\begin{array}{c}\text { TW2 and } \\
\text { TW3 } \\
<\text { TW1 and } \\
\text { TW4 }\end{array}$ & - & - & + & - & - & $\begin{array}{l}\mathrm{KGD}(+1) \\
\mathrm{KGD}(-1) \\
\operatorname{KGD}(-3) \\
\operatorname{KGP}(+1)\end{array}$ \\
\hline 4 & $\mathrm{TW} 2=\mathrm{TW} 3$ & + & + & - & $\begin{array}{l}\mathrm{KGD}(+1) \\
\mathrm{KGP}(+1) \\
\mathrm{KGP}(-1)\end{array}$ & $\begin{array}{l}\mathrm{KGD}(+1) \\
\mathrm{KGP}(+1) \\
\mathrm{KGP}(-1)\end{array}$ & - \\
\hline 5 & $\mathrm{TW} 1=\mathrm{TW} 4$ & - & + & + & $\begin{array}{c}\mathrm{KGD}(+1) \\
\mathrm{KGP}(+1) \\
\mathrm{KGP}(-1)\end{array}$ & $\begin{array}{c}\mathrm{KGD}(+1) \\
\mathrm{KGP}(+1) \\
\mathrm{KGP}(-1)\end{array}$ & $\begin{array}{c}\mathrm{KGD}(+1) \\
\mathrm{KGP}(+1) \\
\mathrm{KGP}(-1)\end{array}$ \\
\hline 8 & $\begin{array}{c}\text { TW3 < TW4 } \\
(\text { TW4 }> \\
\text { TW3) }\end{array}$ & - & - & + & - & - & $\begin{array}{l}\mathrm{KGD}(+1) \\
\operatorname{KGD}(-1) \\
\mathrm{KGD}(-3) \\
\mathrm{KGP}(+1) \\
\end{array}$ \\
\hline 9 & $\begin{array}{c}\text { TW3 }>\text { TW4 } \\
\text { (TW4< } \\
\text { TW3) }\end{array}$ & + & + & - & KGP(-1) & KGP(-1) & - \\
\hline 10 & TW1 > TW4 & + & - & - & $\begin{array}{l}\mathrm{KGD}(-1) \\
\operatorname{KGD}(-2) \\
\operatorname{KGP}(-1)\end{array}$ & - & - \\
\hline
\end{tabular}

TW4 is 2.2 times more than TW3 for a water sample from the source 10; TW4 is 1.8 times higher than TW3; TW4 is 1.3 times higher than TW1; min. TW3 is 2.2 times lower than the maximum TW3.

Table 6

Correspondence of EPPM indices according to histograms of Kirlian photographs luminescence for experimental water samples to the type and degrees of experimental coherent water

\begin{tabular}{|c|c|c|c|c|c|c|c|}
\hline Sign No. & Signs & $\begin{array}{c}\text { Source } \\
1\end{array}$ & $\begin{array}{c}\text { Source } \\
26\end{array}$ & $\begin{array}{l}\text { Source } \\
10 \text { (pump } \\
\text { room) }\end{array}$ & $\begin{array}{c}\text { Coherence } \\
\text { Source } 1\end{array}$ & $\begin{array}{c}\text { Coherence } \\
\text { Source } 26\end{array}$ & $\begin{array}{c}\text { Coherence } \\
\text { Source } 10\end{array}$ \\
\hline 1 & 2 & 3 & 4 & 5 & 6 & 7 & 8 \\
\hline 1 & $\begin{array}{c}\text { Order of mag- } \\
\text { nitude }\end{array}$ & $5 ; 4$ & $5 ; 4$ & 5 & & & \\
\hline 2 & $\begin{array}{c}\text { TW2 and TW3 } \\
<\text { TW1 and } \\
\text { TW4 }\end{array}$ & - & - & + & - & - & $\begin{array}{l}\mathrm{KGD}(+1) \\
\mathrm{KGD}(-1) \\
\mathrm{KGD}(-3) \\
\mathrm{KGP}(+1)\end{array}$ \\
\hline 3 & $\begin{array}{c}\text { TW2 and TW3 } \\
>\text { TW1 and } \\
\text { TW4 }\end{array}$ & + & + & - & $\begin{array}{l}\mathrm{KGD}(-1) \\
\operatorname{KGP}(-1)\end{array}$ & $\begin{array}{l}\mathrm{KGD}(-1) \\
\operatorname{KGP}(-1)\end{array}$ & - \\
\hline 5 & $\mathrm{TW} 2=\mathrm{TW} 3$ & + & + & - & $\begin{array}{l}\mathrm{KGD}(+2) \\
\mathrm{KPV}(+1) \\
\mathrm{KPV}(+2) \\
\mathrm{KPV}(+3) \\
\mathrm{KPV}(-1) \\
\mathrm{KPV}(-2) \\
\mathrm{KPV}(-3)\end{array}$ & $\begin{array}{l}\mathrm{KGD}(+2) \\
\mathrm{KPV}(+1) \\
\mathrm{KPV}(+2) \\
\mathrm{KPV}(+3) \\
\mathrm{KPV}(-1) \\
\mathrm{KPV}(-2) \\
\mathrm{KPV}(-3)\end{array}$ & - \\
\hline
\end{tabular}


Table 6 (Continued)

\begin{tabular}{|c|c|c|c|c|c|c|c|}
\hline 1 & 2 & 3 & 4 & 5 & 6 & 7 & 8 \\
\hline 6 & TW2 > TW3 & - & - & + & - & - & $\mathrm{KDV}(+1)$ \\
\hline 8 & $\begin{array}{c}\text { TW3 }< \\
\text { TW1,2,4 } \\
\end{array}$ & - & - & + & - & - & $\mathrm{KDV}(+1)$ \\
\hline 10 & $\begin{array}{c}\text { TW4 < TW3 } \\
(\mathrm{TW} 3>\text { TW4) }\end{array}$ & + & + & - & $\begin{array}{l}\mathrm{KGD}(-1) \\
\mathrm{KGD}(-2) \\
\mathrm{KGP}(-1) !\end{array}$ & $\begin{array}{l}\text { KGD(-1) } \\
\text { KGD(-2) } \\
\text { KGP(-1)! }\end{array}$ & - \\
\hline 11 & TW4 > TW3 & - & - & + & - & - & $\begin{array}{l}\text { KGD }(+3) \\
\text { KGD }(-3) \\
\operatorname{KGP}(+1)\end{array}$ \\
\hline 13 & $\begin{array}{l}\text { TW4 < TW2 } \\
(\mathrm{TW}>\mathrm{TW} 4)\end{array}$ & + & + & - & $\begin{array}{l}\mathrm{KGD}(-1) \\
\mathrm{KPV}(-1) ! \\
\mathrm{KGP}(-3) !\end{array}$ & $\begin{array}{l}\mathrm{KGD}(-1) \\
\mathrm{KPV}(-1) ! \\
\mathrm{KGP}(-3) !\end{array}$ & - \\
\hline 14 & TW4 > TW2 & - & - & + & - & - & $\begin{array}{l}\text { KGD }(+1) \\
\operatorname{KGD}(-3) \\
\operatorname{KGP}(-1) \\
\end{array}$ \\
\hline 16 & TW4 < TW1 & & & & $\begin{array}{l}\text { KGP(-1)! } \\
\text { KGP(-3)! }\end{array}$ & & \\
\hline 17 & TW4 > TW1 & + & - & - & & - & $\begin{array}{l}\mathrm{KGD}(+1) \\
\mathrm{KGD}(+2) \\
\mathrm{KGD}(+3) !\end{array}$ \\
\hline 18 & $\mathrm{TW} 4=\mathrm{TW} 1$ & - & + & - & - & $\begin{array}{c}\mathrm{KGD}(+1) \\
\mathrm{KGD}(+2) \\
\mathrm{KGD}(+3) \\
\mathrm{KGP}(-2)\end{array}$ & 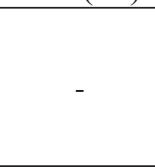 \\
\hline 19 & Min. TW & TW4 & - & TW3 & $\begin{array}{l}\mathrm{KGD}(-1) \\
\operatorname{KGP}(-1) \\
\operatorname{KGP}(-3)\end{array}$ & - & $\begin{array}{l}\mathrm{KGD}(+1) \\
\mathrm{KGD}(+3)\end{array}$ \\
\hline 20 & Max. TW & - & - & TW4 & - & - & $\begin{array}{c}\mathrm{KGD}(-3) \\
+-\end{array}$ \\
\hline
\end{tabular}

Table 7 shows the results of the summary analysis of all the obtained EPM and EPPM indicators to identify the frequency of signs occurrence for coherent water of different polarity and degree.

Table 7

Analysis of the coherence state in the studied water samples according to luminescence histograms of their Kirlian photographs

\begin{tabular}{|c|c|c|c|c|c|c|}
\hline KGV & $\begin{array}{c}\text { Source 1 } \\
\text { Number of } \\
\text { signs }\end{array}$ & $\begin{array}{c}\text { Source 1 } \\
\mathbf{\%}\end{array}$ & $\begin{array}{c}\text { Source 26 } \\
\text { Number of } \\
\text { signs }\end{array}$ & $\begin{array}{c}\text { Source 26 } \\
\mathbf{\%}\end{array}$ & $\begin{array}{c}\text { Source 10 } \\
\text { Number of } \\
\text { signs }\end{array}$ & $\begin{array}{c}\text { Source 10 } \\
\mathbf{\%}\end{array}$ \\
\hline $\mathbf{1}$ & $\mathbf{2}$ & $\mathbf{3}$ & $\mathbf{4}$ & $\mathbf{5}$ & $\mathbf{6}$ & $\mathbf{7}$ \\
\hline \multicolumn{7}{|l}{ KGD: } \\
\hline+1 & 1 & 11 & 2 & 22 & 8 & 42 \\
\hline+2 & 1 & 11 & 2 & 22 & 1 & 5 \\
\hline 3 & 0 & 0 & 1 & 11 & 2 & 10 \\
\hline-1 & 5 & 55 & 3 & 33 & 3 & 16 \\
\hline-2 & 2 & 22 & 1 & 11 & 0 & 0 \\
\hline
\end{tabular}


Table 7 (Continued)

\begin{tabular}{|c|c|c|c|c|c|c|}
\hline $\mathbf{1}$ & $\mathbf{2}$ & $\mathbf{3}$ & $\mathbf{4}$ & $\mathbf{5}$ & $\mathbf{6}$ & $\mathbf{7}$ \\
\hline-3 & 0 & 0 & 0 & 0 & 5 & 26 \\
\hline Total: & 9 & 100 & 9 & 100 & 19 & 100 \\
\hline \multicolumn{7}{|c|}{ KGP: } \\
\hline+1 & 2 & 10 & 2 & 13 & 3 & 60 \\
\hline+2 & 1 & 5 & 1 & 7 & 0 & 0 \\
\hline 3 & 1 & 5 & 1 & 7 & 0 & 0 \\
\hline-1 & $10 !$ & 50 & $7 !$ & 47 & 2 & 40 \\
\hline-2 & 1 & 10 & 2 & 13 & 0 & 0 \\
\hline-3 & 5 & 25 & 2 & 13 & 0 & 0 \\
\hline Total: & 20 & 100 & 15 & 100 & 5 & 100 \\
\hline \multicolumn{7}{|l|}{ KGD + KGP total } \\
\hline+1 & 3 & 10 & 4 & 17 & 11 & 46 \\
\hline+2 & 2 & 7 & 3 & 13 & 1 & 4 \\
\hline 3 & 1 & 3 & 2 & 8 & 2 & 8 \\
\hline-1 & 15 & 52 & 10 & 42 & 5 & 21 \\
\hline-2 & 3 & 10 & 3 & 13 & 0 & 0 \\
\hline-3 & 5 & 17 & 2 & 8 & 5 & 21 \\
\hline Total: & 29 & 100 & 24 & 100 & 24 & 100 \\
\hline
\end{tabular}

According to the data presented, it can be seen that, according to the predominant features of the experimental water samples, the properties of the following coherence types are inherent in them:

water from source 1 - coherent levorotatory 1st and 3rd degrees of coherence ( $52 \%$ and $17 \%$ of signs, respectively);

water from the source 26 - coherent both types of direction, more levorotatory 1 st degree (42\% of signs) and dextrorotatory 1 st degree (17\%);

water from source 10 (pump room) - coherent of both types of direction, more dextrorotatory, mainly with the 1 st degree of coherence $(46 \%)$, and the presence of levorotatory coherence of the 1 st $(21 \%)$ and 3rd degrees $(21 \%)$.

It draws attention to the fact that the use of the coherence criteria obtained experimentally on both types of experimental waters (distilled and natural drinking) are consistent with each other.

However, when analyzing test water directly from natural sources, more signs of coherence were revealed according to the criteria of coherent experimental water prepared with natural drinking water, and when analyzing a sample of water from a pump room - prepared with distilled water. Therefore, it is advisable to use the criteria of both types of experimental waters in studies of determining the water bodies coherence.

The biological experiment consisted of placing zucchini seeds "Skvorushka" and "Chaklun" of the same size $(1 \mathrm{~cm})$ and bulbs of the same size $(1-1.5 \mathrm{~cm})$ on a moist substrate with different water for germination for 14 days.

The length of the shoots and roots was measured, and the mass of the dry residue was determined. The results are presented in Table 8 and Figure 4. 
Table 8

Growth test results for zucchini seeds and onion bulbs for different water samples

\begin{tabular}{|c|c|c|c|c|c|c|c|}
\hline \multirow[b]{2}{*}{ No. } & \multirow[b]{2}{*}{$\begin{array}{c}\text { Name } \\
\text { of water sample/biomaterial }\end{array}$} & \multicolumn{3}{|c|}{ Green sprouts } & \multicolumn{3}{|c|}{ Backs } \\
\hline & & $\begin{array}{c}\text { Q-ty } \\
\text { pieces }\end{array}$ & $\begin{array}{l}\text { Avg length } \\
\text { (cm) }\end{array}$ & $\begin{array}{l}\text { Dry weight } \\
\text { (mg) }\end{array}$ & $\begin{array}{l}\text { Q-ty } \\
\text { pieces }\end{array}$ & $\begin{array}{l}\text { Avg } \\
\text { length } \\
\text { (cm) }\end{array}$ & $\begin{array}{l}\text { Dry } \\
\text { mass } \\
(\mathrm{mg})\end{array}$ \\
\hline & Planting day $07 / 27 / 21$ & & & & & & \\
\hline & Measurement day 17.08.21 & & & & & & \\
\hline 1. & \multicolumn{7}{|c|}{ Source No. 1} \\
\hline 1.1 & Zucchini «Skvorushka» & 10 & 9.5 & 357 & 1 & 5.5 & 68 \\
\hline 1.2 & Zucchini «Chaklun» & 10 & 7.5 & 345 & 1 & 3.8 & 54 \\
\hline 1.3 & Onion bulb & 5 & 8.2 & 280 & 8 & 7.2 & 50 \\
\hline 2. & \multicolumn{7}{|c|}{ Source No. 26} \\
\hline 2.1 & Zucchini «Skvorushka» & 10 & 3.8 & 220 & 1 & 2.6 & 44 \\
\hline 2.2 & Zucchini «Chaklun» & 10 & 3.2 & 194 & 1 & 2.5 & 40 \\
\hline 2.3 & Onion bulb & 5 & 7.3 & 260 & 6 & 6.8 & 46 \\
\hline 3 & \multicolumn{7}{|c|}{ Source (pump room) No. 10} \\
\hline 3.1 & Zucchini «Skvorushka» & 10 & 1.9 & 128 & 1 & 1.9 & 40 \\
\hline 3.2 & Zucchini «Chaklun» & 10 & 1.8 & 116 & 1 & 1.6 & 38 \\
\hline 3.3 & Onion bulb & 5 & 6.4 & 245 & 4 & 5.4 & 42 \\
\hline
\end{tabular}

The presented results of biological growth demonstrate their differences among themselves, as well as the established properties of experimental water samples in terms of its coherence properties.

\section{Conclusions}

1. The presented results showed the best plant growth on water directly from sources, correlated with the results on the quality of its coherence according to the Kirlian luminescence data.

2. The method of Kirlian photography of water droplets on an X-ray film is quite informative for assessing the coherent properties of water by analyzing its gas-discharge glow and can be used as an express method.

3. It is advisable to supplement the identified criteria of water coherence into the existing standards of health-improving water sources.

4. It is necessary to further develop the direction of studying fine-material processes in water by the method of kirlianphotography with the development of an automated analysis of kirlianograms.

\section{References}

1. Vernadskij, V.I. (2004). Biosfera i noosfera [Biosphere and noosphere]. Foreword by R.K. Balandin. Moscow: Ajris-press. Retrieved from http://gromada-i-misto.org/wp-content/ uploads/2017/11/Vernadskiy-Biosfera_Noosfera.pdf [in Russian].

2. Kurik, M.V. \& Pesockaja, L.A. (2014). Kirlianografija zhivyh i kosnyh tel biosfery. [Kirlianography of living and inert bodies of the biosphere]. Dnipropetrovsk: Litograf [in Ukrainian].

3. Kurik, M.V., Pesockaja, L.A., Gluhova, N.V., \& Evdokimenko, N.M. (2015). Kirlinografija jenergo-informacionnyh vzaimodejstvij vody [Kirilnography of energy-informational water interactions]. Dnipropetrovsk: Litograf [in Ukrainian]. 
4. Voejkov, V.L. (2009). Kljuchevaja rol' ustojchivo neravnovesnogo sostojanija vodnyh sistem v biojenergetike [The key role of a stable non-equilibrium state of water systems in bioenergy]. Rossijskij himicheskij zhurnal (Zhurnal RHO im. DI Mendeleeva) - Russian Chemical Journal (Journal of the Russian Chemical Society named after D.I. Mendeleev), 53(6), 41-49. [in Russian].

5. Kirlian S.D. \& Kirlian V.H. (1957). Sposob poluchenija fotograficheskih snimkov razlichnogo roda obektov [A method of obtaining photographic images for various kinds of objects]. Avtorskoe svidetil'stvo - Inventor's certificate No. 106401. G03V 41/00[in Russian].

6. Koltovoj, N.A. (2015). Metod Kirlian [Kirlian method]. Moscow. Retrieved from: https://www.koob.ru/koltovoy/method_kirlian_v_in Russian].

7. Korotkov, K.G. \& Jakovleva, E G. (2014). Primenenie metoda GRV-biojelektrografii v medicine (obzor literatury) [Application of the GDV-bioelectrography method in medicine (literature review)]. Vestnik Sankt-Peter burgskogo universiteta. Medicina-Bulletin of St. Petersburg University. Medicine 2. Retrieved from https://cyberleninka.ru/article/n/primenenie-metoda-grv-bioelektrografi-v-meditsine-obzor-literatury [in Russian].

8. Pisotska L.A. \& Hlukhova N.V. (2014). Sposib otsinky biolohichnoi aktyvnosti vody [Method of biological activity assessment for water]. Patent na korysnu model - Utility model patent Ukraine No. 91003 [in Ukrainian].

9. Pesockaja L.A., Mincer A.P., \& Hlukhova N.V. (2016). Sposob opredelenija stepeni kogerentnosti sostojanija vody [Method for determining the degree of coherence of the state of water]. Patent Ukrainy na izobretenie - Patent of Ukraine for invention No. 112809. [in Ukrainian].

10. Pisotska L.A., Lapytskyi V.M., Botsman K.I. \& Herashchenko S.V. (2007). Sposib otsinky enerhoinformatsiinoho stanu ridynno faznoho obiektu i prystrii dlia yoho zdiisnennia [A method for assessing the energy information state of a liquid-phase object and a device for its implementation]. Patent Ukrainy na korysnu model - Utility model patent Ukraine No. 22212 [in Ukrainian].

11. Pisotska, L. A., Mintser, O. P., \& Hlukhova, N.V. (2015). Prystrii dlia reiestratsii zobrazhennia kirlian-svitinnia biolohichnykh obiektiv [Device for recording the image of the Kirlian glow of biological objects]. Patent na korysnu model. Pat, 100879.

12. Pesockaja, L.A., Mincer, O.P. \& Hlukhova, N.V. (2015). Prystrii dlia reiestratsii zobrazhennia kirlian-svitinnia biolohichnykh obiektiv. [Device for registration of the Kirlian imageglow of biological objects]. Patent Ukrainy na korysnu model. - Utility model patent Ukraine No. 100879 [in Ukrainian].

13. Mandel, P. (1983). Energetische Terminalpunkt-Diagnose. Engan [in Norway].

14. Krasnobryzhev, V.G. \& Kurik, M.V. (2010). Svojstva kogerentnoj vody [Properties of coherent water]. Kvantovaja Magija - Quantum Magic 7 (2), 2161-2166 [in Russian].

15. Krasnobryzhev, V.G. (2012). Global'nyj tehnologicheskij resurs makroskopicheskoj nelojal'nosti [Global technological resource for macroscopic disloyalty]. LAP LAMBERT Academic publishing [in Russian].

16. Krasnobryzhev, V.G. (2007). Sposob i oborudovanie dlja modifikacii topliva [Method and equipment for fuel modification. Sposób i urządzenie do modyfikacji paliwa]. Patent Pol'shi na poleznuju model' - Polish utility model patent No.207357 [in Poland]. 